\title{
OBSTETRIC VIOLENCE: A WOMEN'S HUMAN AND PERSONALITY RIGHTS VIOLATION
}

\section{VIOLÊNCIA OBSTÉTRICA: UMA VIOLAÇÃO DE DIREITOS HUMANOS E DA PERSONALIDADE DAS MULHERES}

\section{CYNTHIA LOURENÇO TACH}

Advogada e mestre em Direito Internacional dos Direitos Humanos pela University of Groningen (Holanda). Especialista em Direito Internacional pela Faculdade Damásio. Bacharela em direito pela Universidade Estadual de Maringá (UEM).

\section{BRIGIT TOEBES}

Docente da Faculdade de Direito da University of Groningen (Holanda) e Presidente do Centro de Estudos de Direito da Saúde em um Contexto Global no Departamento de Estudos Jurídicos Transfronteiriços, University of Groningen. Doutora em Direitos Humanos pela Utrecht University (Holanda). Mestre em Direito Holandês e em Direito Internacional Público também pela Utrecht University (Holanda).

\section{JULIANA MARTELI FAIS FERIATO}

Docente e vice-coordenadora do Programa de Pós-Graduação Stricto Sensu (Mestrado e Doutorado) em Ciências Jurídicas da Unicesumar. Doutora e mestre em Direito pela Universidade Federal de Santa Catarina (UFSC)

\section{ABSTRACT}

Objective: The present article is aimed to analyse the phenomenon of obstetric violence as a type of violation of women's human rights. A great incidence of physical, sexual and psychological offenses against women during pregnancy, childbirth and the puerperium committed by healthcare workers has been 
documented worldwide. Labelled as 'obstetric violence', this offence has been understood as a specific type of human rights violation that hampers women's sexual and reproductive rights and is committed in both public and private healthcare facilities, as well as from poor health system conditions. Nevertheless, obstetric violence is still a poorly understood phenomenon. This article will analyse how obstetric violence has been defined, measured and understood by specialists, by focusing on its concept, formats, and consequences for victims, as well as on the contributing factors that influence its occurrence.

Methodology: The applied methodology was the qualitative method through documentary studies, in which primary sources and English, Spanish and Portuguese-language research publications from different fields of study were used, including public health, public international law, and human rights.

Results: The paper concludes by suggesting how the international human rights framework can be used to better address obstetric violence. The Convention on the Elimination of all Forms of Discrimination against Women and the Inter-American Convention on the Prevention, Punishment and Eradication of Violence against Women are key treaties that establish for States Parties the obligation to pursue, by all appropriate means and without delay, a policy of eliminating discrimination and gender-based violence against women, including in the field of health.

Contribution: The article has as contribution the exposure a little-known subject about obstetric violence as a type of violation of women's human rights.

Keywords: Obstetric violence; abuse and mistreatment in healthcare facilities; women's human rights violation; the medicalization of the natural process of childbirth.

\section{RESUMO}

Objetivo: O presente artigo tem como objetivo analisar o fenômeno da violência obstétrica como tipo de violação dos direitos humanos da mulher. Vários casos de ofensas físicas, sexuais e psicológicas contra mulheres durante a gravidez, o parto e o puerpério cometidos por profissionais de saúde tem sido documentada em todo o mundo. Intitulada 'violência obstétrica', essa ofensa é entendida como um tipo específico de violação de direitos humanos que prejudica os direitos sexuais e reprodutivos das mulheres e é cometida em unidades de saúde públicas e privadas, bem como devido à condições precárias no sistema de saúde. Contudo, a violência obstétrica ainda é um fenômeno pouco compreendido. Nesse sentido, este artigo analisará como a violência obstétrica é definida, mensurada e compreendida por especialistas, concentrando-se na definição adotadas, nas formas e consequências para as vítimas, bem como nos fatores contribuintes que influenciam a sua ocorrência. 
Metodologia: A metodologia foi o método qualitativo, através de estudos documentais, nos quais fontes primárias e artigos científicos em inglês, espanhol e português de diferentes áreas de estudo foram utilizados, incluindo saúde pública, direito internacional público e direitos humanos.

Resultados: $\mathrm{O}$ artigo conclui sugerindo como a estrutura internacional de direitos humanos pode ser utilizada para combater a violência obstétrica. A Convenção sobre a Eliminação de Todas as Formas de Discriminação contra as Mulheres e a Convenção Interamericana para Prevenir, Punir e Erradicar a Violência contra as Mulheres são tratados fundamentais que estabelecem para os Estados Partes a obrigação de buscar, por todos os meios apropriados e sem demora, uma política de eliminação da discriminação e da violência de gênero contra as mulheres, inclusive no campo da saúde.

Contribuições: $O$ artigo tem como contribuição a exposição de um assunto pouco conhecido sobre a violência obstétrica como tipo de violação dos direitos humanos da mulher.

Palavras-chave: Violência obstétrica; abuso e maus-tratos em estabelecimentos de saúde; violação de direitos humanos das mulheres; medicalização do parto.

\section{INTRODUCTION}

From the moment when pregnancy and childbirth ceased to be domestic sphere phenomena and started to occur in the medical field, the hospitalization and medicalization of childbirth became recurrent. With this, violent and abusive practices against pregnant women have arisen and became prominent in the last decades, but still unknown to victims and invisible to society. (ZANARDO, 2017, p. 2). Each year, numerous cases of women suffering bodily violations and coercive behaviour in healthcare facilities during pregnancy, childbirth and postpartum period are recorded around the globe. Similar to the situation of domestic violence in the 1960s, this type of abuse and mistreatment towards childbearing women today is a current offence but still without a universally adopted legal name. (BUCCl; KOCH, p. 313).

Labelled as 'obstetric violence' in Latin America, this offence has been understood as a specific type of human rights violation and personality rights 
violation ${ }^{1}$ which hampers women's sexual and reproductive rights and is committed in both public and private healthcare facilities, such as hospitals and medical clinics, as well as from poor health system conditions. (MESECVI, 2014, p. 39). ${ }^{2}$ The concept has resulted in the development of a domestic legal framework in Latin American countries addressing such violations at the individual responsibility's level, which specifically locates obstetric violence at the nexus of violence against women since it violates women's rights and freedoms. (WILLIAMS et al., 2018, p. 1208). ${ }^{3}$

However, at the international level, the existing research on obstetric violence is still limited, which does not mean the problem is simply attributed to isolated areas. Also, a lack of consensus is still present on how the issue should be measured. (WORLD HEALTH ORGANIZATION, 2015). This reflects the extent to which the theme has been obscured from public awareness, which complicates the task of defining the problem and identifying solutions.

In this regard, given the seriousness of the topic, an analysis of obstetric violence as a women's human rights violation will focus firstly on its concept, formats, and the consequences for victims, and then on the contributing factors that influence its occurrence, in order to contribute to the acknowledgement of the theme and foster accountability in accordance with human rights standards. The paper concludes by illustrating how the international human rights system can be used to better address

\footnotetext{
${ }^{1}$ Within the domestic framework, under the State's constitution, human rights are categorized as individual rights; a set of rights whose content reflects an individual's protected sphere of interest. Therefore, they are also synonymous with the first generation of rights, as they represent the classic civil and political rights before the State. In light of this, it can be argued that obstetric violence is also an indication of larger individual rights violations, protected under a particular constitution. (RAMOS, 2014, seção 2.5.1). Within Brazilian domestic framework, rights of personality are rights of the human person taken in himself and his projections in society, provided by the law in the defense of humans' innate values, such as life, physical health, privacy, respect, honor and many others. (BITTAR, 2014, seção 1.1).

${ }^{2}$ With respect to the terminology, obstetric violence is a term adopted in Latin America, but it is not yet in use in international human rights law. In order to address it under the existing international human rights framework, scholars and international organizations refer to "abuse and mistreatment against women during childbirth". At the regional level, the Committee of Experts of the Follow-up Mechanism of the Belém do Pará Convention was the first body of an international organization to recognize obstetric violence as a human rights violation. MECANISMO de Seguimiento de la Convención Belém do Pará (Mecanismo de Seguimiento de la Convención Belém do Pará, 2014, p. 39).

3 For example, Venezuela became the first nation to develop legislation regarding abuse and mistreatment of pregnant women by healthcare workers, and the first do define 'obstetric violence' as a legal term, within the context of gender-based violence. (REPÚBLICA BOLIVARIANA DE VENEZUELA, 2007).
} 
obstetric violence, with some suggestions to be adopted at the national level to develop accountability measures under a human rights-based approach.

\section{UNDERSTANDING OBSTETRIC VIOLENCE}

Obstetric violence is a poorly understood phenomenon. (WORLD HEALTH ORGANIZATION, 2015). Due to limited research on the subject, substantial gaps in knowledge and data persist about women's abuse and mistreatment during childbirth in healthcare facilities. (KUKURA, 2018, p. 724-725). Moreover, the absence of a universally accepted definition for such acts requires scholars and women's advocates to utilize their own vocabulary of obstetric violence in order to better comprehend and identify adequate responses. (KUKURA, 2018, p. 725). As this paper will focus on obstetric violence, a topic still incomprehensible internationally, it is essential that it centres its analysis on the understanding of the topic, such as definition and constitutive elements, as a first step to address it and foster accountability in accordance with human rights standards. Furthermore, dealing with a multi-factorial phenomenon in which social, cultural, and structural contexts create conditions to its occurrence can no longer be addressed only by a solid legal perspective, at risk of generating further gaps rather than solving them. (BOUCHARD; MEYER-BISCH, 2016, p. 201). Violence can only be eliminated after being accurately understood, and, for that, it is essential to understand the victim's background and experience. In light of this, sub-section 1 will focus on the concept, forms, and consequences of obstetric violence, while sub-section 2 will analyse the two main contributing factors that enable its occurrence.

\subsection{CONCEPT AND FORMS OF OBSTETRIC VIOLENCE}

The World Health Organization has acknowledged that 'many women experience disrespectful and abusive treatment during childbirth in facilities worldwide' which 'not only violates the rights of women to respectful care, but can 
also threaten their right to life, health, bodily integrity, and freedom from discrimination.' (WORLD HEALTH ORGANIZATION, 2015). However, as the Organization has noted (2015), 'despite the existing evidence', there is 'no international consensus on how disrespect and abuse should be scientifically defined and measured', which are the primordial steps to comprehend the phenomenon.

Started from the efforts of feminists, researchers, and civil society organizations, obstetric violence has emerged as a legal concept in Latin America to evince the profound harm some women experience while receiving reproductive and maternal care in healthcare facilities. (KUKURA, 2018, p. 763). As described by Murray de Lopez (2015, p. 6-7), obstetric violence is 'a widely used and accepted term in Latin American literature' related to physical and psychological violence suffered by women in public health institutions, and inflicted during pregnancy, labour, and puerperium.

Various practices constituting obstetric violence have been identified by researchers in the last years, ranging from less dramatic forms, such as humiliation, to more extreme instances of physical and sexual abuse. (BOWSER; HILL, 2010, p. 9). In 2015, a systematic review was conducted in thirty-four countries aiming to synthesize qualitative and quantitative evidence on the abuse and mistreatment of pregnant women in health facilities in order to 'inform the development of an evidence-based typology of the phenomenon'. As a result, seven domains were identified, which consist of physical abuse, sexual abuse, verbal abuse, stigma and discrimination, failure to meet professional standards of care, poor rapport between women and providers, and health system conditions and constraints. ${ }^{4}$ As explained by Bohren et al. (2015, p. 2), these acts can occur 'at the level of interaction between the woman and healthcare provider' (patient-healthcare provider relationship), as well as 'through systematic failures at the health facility and health system levels', where under-resourced units affect the quality of care women receive.

At the level of interaction between patient and health worker, obstetric

\footnotetext{
${ }^{4}$ Given the brevity of the study, these categories will not be individually analyzed, since a detailed analysis of all categories would be impracticable. For more information on each one, please see BOHREN et al., 2015, p. 1.
} 
violence can be perpetrated by physicians, nurses, medical students, and other professional staffs present during prenatal, labour and puerperium. (KUKURA, 2018, p. 727). Most acts range from verbal offences, abandonment of care to the most severe level of violence, such as sexual and physical violence or even maternal death. Regarding verbal abuses, the most common manifestations are disrespectful comments, such as scolding, irony, insults, threats, blame, and humiliation. Verbal offenses are usually related to women's behaviour during labour, women's concerns and decisions about their treatment, or regarding women's pre-existing health conditions, cultural, race, ethnic, socio-economic, and other backgrounds, or marital status. (KUKURA, 2018, p. 753).

Physical abuse are violations of the victim's bodily integrity and may occur in numerous ways, ranging from denial of pain relief, use of force, use of unconsented medical procedures to the performance of forced surgeries. These unconsented or coerced medical interventions refer to health practices without the consent of the patient or obtained in a vitiated form and performed only for medical convenience. (KUKURA, 2018, p. 735). ${ }^{5}$ Obstetric violence can also occur through sexual abuse of patients during childbirth. A frequent abuse committed by nurses and doctors is during vaginal exams, where the vagina is penetrated for checking the dilation, effacement, and position of the cervix. Normally performed without woman's consent, these examinations are excessive and dehumanizing, often conducted in non-private settings. (BOHREN et al., 2015, p. 11). Another example of sexual abuse is the practice of the 'Husband Stitch'. It consists of an unnecessary extra stitch performed by some doctors during episiotomy repair for the purpose of tightening the vagina, and thus, creating more sexual pleasure for the woman's male partner. (KUKURA, 2018, p. 736).

On the other hand, obstetric violence derived from poor health system conditions is generally the result of a lack of medical resources and structural conditions. It affects the quality of care provided and directly increase the risks women face during pregnancy and delivery. Examples of such institutional violence

${ }^{5}$ This view will be discussed in sub-section 2 . 
are failure to ensure patient's privacy, absence of individual hospital bed, lack of medical supply, and staffing shortage. (BOHREN e al., 2015, p. 7). In research conducted with patients from public maternity hospitals in the Dominican Republic, health system conditions emerged as the main area in which pregnant women experienced obstetric violence. As a result, $65 \%$ of the participants have shared hospital beds, lacked clothes or covering, and felt physically exposed to patients and healthcare providers. (CASTRO; SAVAGE, 2019, p. 5). ${ }^{6}$

Overall, various types of abuse and mistreatment committed in healthcare facilities can amount to obstetric violence, with some occurring to a greater degree and others to a lesser extent. It can also happen through the interaction between the woman and healthcare provider or be derived from poor health system conditions. However, this adopted categorization does not intend to be exhaustive nor does it suggest that the offense occurs in isolation. (KUKURA, 2018, p. 728). Many reported incidents involve multiple forms of conduct that overlap, which demonstrates how complex obstetric violence can become.

In the absence of a definition of obstetric violence within the international human rights framework, the term adopted by scholars and women's advocacy can be applied to all types of conduct. Due to the stigma and discrimination faced by women from different backgrounds and the subjectivity inherent in each violence experienced, obstetric violence can encompass each one of the seven domains previously mentioned, transforming the task of defining and categorizing it with precision aggravated. (KUKURA, 2018, p. 728). Moreover, obstetric violence endangers the physical and psychological integrity of the woman and increases the chances of maternal death during a moment of intense fragility and vulnerability. (BUCCI; KOCK, 2017, p. 315). The physical and mental consequences will be discussed in more detail in the next section.

\footnotetext{
${ }^{6}$ Instead of associating it with a type of mistreatment derived from poor quality care, women tend to normalize poor health system conditions, remaining positive about their overall experiences and grateful for the medical attention they received. This behaviour evidences the resignation of poor women to experience childbirth according to the only moral regime designated for them.
} 


\subsection{CONSEQUENCES FOR VICTIMS}

Under the human rights-based approach, all women regardless distinction must receive high-quality care before and during pregnancy, labour, childbirth and the postpartum period. (SAY; CHOU, 2018, p. 2). Even that 'all intervention into the physiological birthing process entails some degree of risk', such risks, when properly informed, are normally pondered by the woman against the expected benefits of the medical procedure. (KUKURA, 2018, p. 754). However, when the medical intervention results from a coerced or unconsented decision, the resulting consequences constitute violations to the woman's bodily and mental integrity. (KUKURA, 2018, p. 754).

Obstetric violence can cause several types of physical and psychological harm to the woman. (KUKURA, 2018, p. 754-757). From each type of abuse or mistreatment, different injuries may arise, which can be of short or long-term duration. Caesarean section is a common example of an often unwanted and unnecessary medical intervention that can generate physical damage. In short-term, research shows that caesareans are likely to result in blood clots and stroke, surgical injury, infection, early postpartum haemorrhage, intense and prolonged postpartum pain, and obstetric shock. (SANDALL et al., 2018, p. 1351). In long-term, caesareans may cause pelvic pain adhesions, small bowel obstruction, caesarean scar ectopic

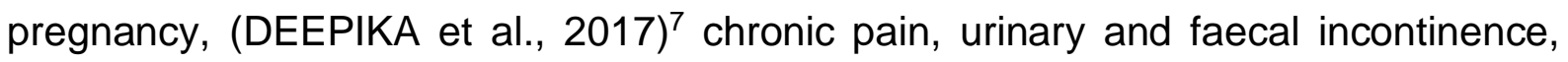
and even involuntary infertility. (SANDALL et al., 2018, p. 1351). Other unwanted interventions, such as episiotomy, forceps-assisted or vacuum-assisted delivery, can also produce short and long-term physical harm and may generate the need for additional procedures, which leads to further injuries. (KUKURA, 2018, p. 755).

Apart from physical consequences, the psychological effects of obstetric violence also impair women's postpartum well-being, and may create lasting injuries. Many women report experiencing post-traumatic stress disorder from stressful birth

\footnotetext{
7 'Caesarean scar ectopic is one of the rarest of all ectopic pregnancies. It is defined as when a blastocyst implants on a previous Caesarean scar. The incidence of caesarean scar ectopic has increased due to raise of number of caesarean deliveries'.
} 
experiences, especially when faced with unconsented or coerced medical procedures. (KUKURA, 2018, p. 756). In a study conducted in Chiapas, Mexico, the interviewed women reported experiencing feelings of failure, humiliation, and loss of expectations after having suffered obstetric violence. They also described 'being left with conflicting emotions and began analysing their behaviour during pregnancy and birth' with feelings of guilt. (MURRAY DE LOPEZ, 2018, p. 67). Long-term psychological consequences may also manifest in feelings of powerlessness, postpartum depression, and 'the need to avoid all associations with birth.' (KUKURA, 2018, p. 756).

Additionally, the emotional consequences of obstetric violence make women less willing or able to complain about the received treatment and seek reparations or help. For many, complaining about the violence suffered may suggest ungratefulness about their pregnancy and birth, leading them to remain silent. (KUKURA, 2018, p. 756). This type of repression, as illustrated by Murray de Lopez (2018, p. 67), 'reveals ways in which women employ tactics (silence and avoidance) that they often use in other aspects of their lives to deal with everyday forms of oppression and violence.' Perceived as any other gender-based discrimination received on a daily basis, some women are resigned to accepting and interpreting obstetric violence as "normal" consequences of childbirth or as something caused by themselves. (CASTRO; SAVAGE, 2019, p. 10.) This suggests that not only personal factors influence women's behaviour in condoning obstetric violence but also situational factors, such as social, cultural and institutional pressures. Given the importance of these determinants, separate attention will be paid to them below.

\section{POTENTIAL FACTORS CONTRIBUTING TO OBSTETRIC VIOLENCE}

Violence in general 'cannot be attributed to a single factor.' Instead, it is the result of a complex interaction of individual, social, and cultural contexts allied with environmental relationships. (KRUG et al., 2002, p. 1085). Accordingly, there is no single factor that explains obstetric violence. As a multi-factorial phenomenon, 
(BOWSER; HILL, 2010, p. 3), obstetric violence is triggered by social, cultural and structural determinants which create or enhance conditions where abuse and mistreatment against women during pregnancy, labour, childbirth and postpartum period are enabled. (KUKURA, 2018, p. 725).

Many factors have been highlighted by scholars as potential contributors to obstetric violence, and some are also common in most types of violence, such as poverty, social inequalities, as well as stigma and discrimination. (BOWSER; HILL, 2010, p. 8). ${ }^{8}$ Nevertheless, this section will examine only two features which are considered by the authors as key contributing factors of obstetric violence: the medicalization of childbirth, seen as one factor that negatively impact patienthealthcare provider relationship (KUKURA, 2018, p. 770), and the socio-cultural norms related to gender and maternity allied with discrimination based on women's specific attributes, which influence how maternity care is provided in healthcare facilities. The importance of analysing contributing factors lies in explaining the origin of the violence and in developing targeted measures to address such barriers as a way to prevent and reduce cases of obstetric violence. (KRUG, 2002, p. 1085). Thus, in order to efficiently understand and respond to obstetric violence, it is fundamental to understand the potential contributors.

\subsection{THE MEDICALIZATION OF THE NATURAL PROCESS OF CHILDBIRTH}

From the moment that pregnancy and childbirth ceased to be a domestic phenomenon and began to occur in the medical context, the hospitalization and medicalization of the natural process of childbirth became recurrent, and significantly transformed the way society perceives it. (ROHDE, 2016, p. 5). In order to reduce birth risks and maternal mortality, childbirths started to be understood as 'pathological processes in need of medical care rather than a normal, physiologic process.' (KUKURA, 2018, p. 769). Therefore, asserting control over maternal

\footnotetext{
${ }^{8}$ Some of the factors identified by scholars are: normalization of obstetric violence, lack of community engagement and oversight, financial barriers, lack of autonomy and empowerment, lack of liability and defensive medicine, economic pressures, among others. For further information, see: BOWSER; HILL, 2010 , p. 8.
} 
healthcare has become an increasingly technological matter. However, when obstetric interventions transform into unnecessary routine conducts mostly for medical convenience, the medicalization of childbirth can result in neglect of patient's preferences or respect for their rights, while focusing solely on the medical procedure. (VACAFLOR, 2016, p. 67).

The medicalization of the natural process of childbirth is reflected in high rates of intervention around the world, and caesarean section (CS) is the best example to illustrate it. A study conducted in 2018 with data from 169 countries showed that $21,1 \%$ of births around the world occurred by CS in 2015, which was almost double the proportion registered in 2000 (12,1\%). (SANDALL et al., 2018, p. 1349). In particular countries, such as the Dominic Republic and Brazil, CS rates account for more than $50 \%$ of all births occurred in health facilities, and almost reaching universal use when performed in private health sectors. (BOERMA et al., 2018 , p. 1343-1344). The fact that caesarean rates range from $6,3 \%$ to $59,3 \%$ depending on the country demonstrates that medical need is not the main reason for such high rate variation.' (KUKURA, 2018, p. 770).

As noted by Kukura (2018, p. 770), 'the medicalization of childbirth has the potential to impact negatively the relationship between patient and healthcare provider in several ways.' As medical intervention removes the woman as an agent in her own childbirth experience and transforms her as a patient requiring medical care, it modifies power dynamics between women and healthcare professional, placing the physician in control of the situation due to his/her professional knowledge. (KUKURA, 2018, p. 770). In this 'medicalized birth model', some authors identify a process called objectification of the patient. (CHAUÍ, 1998; REGO, 2003; MARTIN, 2006; In AGUIAR; D'OLIVEIRA, 2010). By this, a woman has her subjectivity annulled and transformed into a mere object of medical analysis and intervention, devoid of any power or right over the procedures to be performed on her own body. As a consequence, the bonds between professionals and patients weaken (called as crisis of confidence), and the women's decisions regarding her birthing process become trivialized. (AGUIAR; D'OLIVEIRA, 2010). She may be viewed as difficult or irresponsible when asking for additional information or questioning a provider's 
decision towards a medical intervention, resulting in an offensive response from the professional. (KUKURA, 2018, p. 770).

\subsection{SOCIO-CULTURAL NORMS AND DISCRIMINATION BASED ON WOMEN'S SPECIFIC ATTRIBUTES}

Socio-cultural norms and attitudes relating to gender and maternity also shape access and delivery of maternal healthcare for women, creating conditions for obstetric violence. (KUKURA, 2018, p. 775.) ${ }^{9}$ Women's freedom and autonomy in terms of sexual and reproductive health have been historically restricted based on harmful patriarchal and gender stereotypes. (CORTE INTERAMERICANA DE DIREITOS HUMANOS, 2016, para. 243). Under patriarchal views, men have been socially and culturally assigned a preponderant role as decision-makers over women's bodies, contributing to transform women's social roles as having a predominantly reproductive function. (CORTE INTERAMERICANA DE DIREITOS HUMANOS, 2016, para. 243). Consequently, the patient-healthcare provider relationship reflects and perpetuates these patriarchal power dynamics (KUKURA, 2018 , p. 770.), resulting in distinctions, restrictions or even exclusions in access to maternal healthcare for women, which culminates in disrespectful and abusive acts that undermine or nullify women's sexual and reproductive rights. (CORTE INTERAMERICANA DE DIREITOS HUMANOS, 2016, para. 243).

Gender norms regarding women's social role as mothers further increase conditions for the occurrence of obstetric violence. (AGUIAR; D'OLIVEIRA, 2010; KUKURA, 2018, p. 776). As described by Kukura (2018, p. 776), 'society's widespread expectation of maternal self-sacrifice [...] suggests that good mothers are those who subordinate their own needs and bodies in service of their children and families.' These cultural norms, which expect women to be altruistic and sacrificing their bodies for their children, are also reflected during maternal

${ }^{9}$ For instance, the gender perspective emphasizes patriarchy, power relations, and hierarchical constructions of masculinity and femininity as a predominant and pervasive driver of the problem. (WHO; LONDON SCHOOL OF HYGIENE AND TROPICAL MEDICINE, 2010, p. 6). 
healthcare. Hence, women who contest these entrenched maternal values and refuse to follow medical advice for unnecessary procedures are often viewed as selfish, creating a conflict between mother and child, and, thus, condemned by the local community. (KUKURA, 2018, p. 776-777).

Additionally, discriminatory behaviours against certain groups of women based on race, ethnicity, age, HIV status, financial status, and education levels also enhance the vulnerability to obstetric violence. (BOWSER; HILL, 2010, p. 21; CASTRO; SAVAGE, 2019, p. 7). Assumptions about a woman's prior behaviour and marital status also trigger discrimination in healthcare facilities. (BOHREN et al., 2015 , p. 15). The most common manifestations of discriminatory acts are women being scolded for being too young to be pregnant, being refused services because of HIV/AIDS or low educational status, and discriminatory care linked to caste and tribe. (BOWSER; HILL, 2010, p. 21-22). As an example, a 2002 study conducted in a public hospital in São Paulo, Brazil, found that the relationship between health professionals and women from disadvantaged socioeconomic backgrounds is frequently marked by distrust, disrespect, conflict, and maltreatment. (HOTIMSKY et al., 2002, p. 1307). Discriminatory behaviours against women from vulnerable and marginalized groups were also mentioned in the study as a factor in the use of unnecessary and painful interventions. Medical records showed the use of episiotomy especially in black, poor, and foreign women (HOTIMSKY et al., 2002, p. 1307), and the use of oxytocin, amniotomy, and less use of analgesia in women with lower level of schooling. (ANDRADE et al., 2016, p. 35).

These harmful norms and stereotypes shaping the maternity care culture also influence the victim's access to justice and the legal system's response to obstetric violence. (KUKURA, 2018, p. 778). Regardless of whether this is due to shame, perceptions of stigma, or a lack of awareness, women still doubt whether their suffered injuries are worthy of complaint. (KUKURA, 2018, p. 724). Additionally, victims tend to perceive obstetric violence as normal consequences of childbirth or something triggered by their own conduct (CASTRO; SAVAGE, 2019, p. 10), believing they might show ungratefulness if complaining about the received treatment. (KUKURA, 2018, p. 756). However, when the minority decides to 
adjudicate their rights over the abuse, coercion, and violence suffered, the current legal framework is mostly inadequate or flawed in providing justice, normally due to the absence of a specific remedy, judicial delay, lack of transparency, gender bias, among others. (KUKURA, 2018, p. 778-779).

\section{CONCLUSION}

In summary, this article has addressed a specific women's human rights violation known as obstetric violence, by analysing its contextual elements from a human rights perspective. Obstetric violence takes multiple patterns, and, as any other forms of violence, it is harmful and detrimental to the physical and mental health of women. It occurs in healthcare settings by patient-healthcare provider relationship, as well as through systematic failures at the health system levels. Apart from physical consequences, the psychological effects derived from it also impair women's postpartum well-being and may create lasting injuries. Although research on how women experience obstetric violence is still insufficient, enough evidence does show that particular groups of women suffer greater physical and emotional harm because of socio-cultural norms, gender and patriarchal stereotypes, and discrimination based on specific attributes. These harmful norms and stereotypes also impede women's access to justice either because they often perceive obstetric violence as normal consequences of childbirth caused by their fault or because of a flawed and discriminatory domestic justice system which does not deliver justice to victims.

Addressing obstetric violence from a human rights perspective requires reshaping harmful socio-cultural norms and gender stereotypes which contribute to a maternal care culture that enables and encourages such conduct in the health system. Necessary changes in the domestic legal system are also required in order to provide meaningful prevention and reparation for victims. Therefore, the use of the international human rights framework is an important venue for legal, social and cultural change. International human rights law includes States' fundamental 
commitments and obligations to enable women to experience pregnancy and childbirth as part of their enjoyment of sexual and reproductive health rights and living a life of dignity. By expressly enshrining State's duties to adequately protect women from discrimination and violence in all spheres, and to safeguard women's entitlement to enjoy and exercise all human rights and freedoms guaranteed in their texts, specific international and regional conventions addressing gender-based discrimination and violence have the power to promote international pressure, to persuade legal and social transformation, and to foster accountability in accordance with human rights standards.

The Convention on the Elimination of all Forms of Discrimination against Women and the Inter-American Convention on the Prevention, Punishment and Eradication of Violence against Women are key treaties that establish for States Parties the obligation to pursue, by all appropriate means and without delay, a policy of eliminating discrimination and gender-based violence against women, including in the field of health. Such imperative also enables individuals and civil society to monitor and demand States' commitment to observe these obligations. Additionally, the rigorous structures from both global and regional human rights systems in place to monitor human rights violations - such as the special procedures from the Human Rights Council and the individual complaints mechanism through treaty bodies - are also fundamental structures to ensure political accountability, to contribute to legislative reform, to influence policy and to guide professional standards for health care.

As such, there is little doubt that the international human rights system can be adopted in efforts to end obstetric violence. It can either be used by recognizing and proclaiming obstetric violence it as a new type of human rights violation that undermines fundamental rights and freedoms of women, or by requiring States to uphold their human rights obligations and commitments derived from international documents towards the protection of the lives and health of women searching for reproductive and maternal healthcare. Either way, States must recognize the centrality of human rights to developing appropriate laws, policies, national women reproductive health strategies and complaint mechanisms, ensuring that a human 
rights-based approach is applied to healthcare and accountability measures for addressing obstetric violence. Apart from this, what needs to be clear is that only a strong political will allied with a multi-faceted approach which contemplates public health, human rights, and ethical perspectives to protect women's right to be free from violence will be the best solution to ensure respectful and dignified care for women during pregnancy, childbirth, and puerperium in healthcare facilities.

\section{REFERENCES}

AGUIAR, Janaína Marques e D'OLIVEIRA, Ana Flávia Pires Lucas. Violência institucional em maternidades públicas sob a ótica das usuárias. Interface Comunicação, Saúde e Educação, 2010. Available at: http://www.scielo.br/pdf/icse/2010nahead/aop4010.pdf >. Accessed on: Dec. 22, 2019.

ANDRADE, Priscyla de Oliveira Nascimento et al. Fatores associados à violência obstétrica na assistência ao parto vaginal em uma maternidade de alta complexidade em Recife, Pernambuco. Revista Brasileira Saúde Maternidade Infantil, vol. 16, issue 1, pp. 29-37, Jan.-Mar., 2016

BITTAR, Carlos Alberto. Os Direitos da Personalidade. São Paulo: Saraiva, 2014.

BOERMA, Ties et al. Global epidemiology of use of and disparities in caesarean sections. The Lancet, vol. 392, issue 10155, p. 1341-1348, Oct. 2018.

BOHREN, Meghan A. et al. The mistreatment of women during childbirth in health facilities globally: a mixed-methods systematic review. PLoS Med 12(6): e1001847, jun. 2015.

BOUCHARD, Johanne e MEYER-BISCH, Patrice. Intersectionality and interdependence of human rights: same or different? The Equal Rights Review, n. 16 , p. 186-203, 2016.

BOWSER, Dianna e HILL, Kathleen. Exploring evidence for disrespect and abuse in facility-based childbirth: report of a landscape analysis. Harvard School of Public Health, University Research Co., LLC. USAID-TRAction Project, Sep. 20, 2010.

BUCCI, Daniela e KOCH, Camila. Os novos parâmetros da Corte Inter-americana de Direitos Humanos sobre violência obstétrica e os potenciais impactos para a proteção das mulheres no Brasil. In: Congresso Brasileiro de Direito 
Internacional, 15., 2017, Florianópolis. Anais do Congresso: Direito Internacional em Expansão, vol. 10, p. 313-331.

CASTRO, Arachu e SAVAGE, Virginia. Obstetric violence as reproductive governance in the Dominican Republic. Medical Anthropology, vol. 38, issue 2, 2019.

CONVENÇÃO Interamericana para Prevenir, Punir e Erradicar a Violência contra a Mulher (Convenção de Belém do Pará) = Inter-American Convention on the Prevention, Punishment, and Eradication of Violence against Women (Convention of Belém do Pará). 9 junho 1994. Available at: <http://oas.org/juridico/portuguese/treaties/a-61.htm>. Accessed on: Oct. 20, 2019.

CONVENÇÃO sobre a Eliminação de Todas as Formas de Discriminação contra as Mulheres $=$ Convention on the Elimination of All Forms of Discrimination against Women. 18 dezembro 1979.Available at: <http://www.planalto.gov.br/ccivil_03/decreto/2002/D4377.htm>. Accessed on: Oct. 20, 2019.

CORTE Interamericana de Direitos Humanos (CIDH), Caso I.V. vs. Bolivia, Excepciones Preliminares, Fondo, Reparaciones y Costas. Sentencia de 30 Noviembre de 2016, Series C № 329. Available at: <http://www.corteidh.or.cr/docs/casos/articulos/seriec_329_esp.pdf>. Accessed on: Dec. 23, 2019.

DEEPIKA et al. A rare case report of caesarean scar ectopic pregnancy. Journal of Clinical and Diagnostic Research, vol. 11, issue 8, QD10-QD1, Aug. 2017.

HOTIMSKY, Sonia Nussenzweig et al. O parto como eu vejo... ou como eu o desejo? Expectativas de gestantes, usuárias do SUS, acerca do parto e da assistência obstétrica. Cad. Saúde Pública, vol. 18, issue 5, p. 1303-1311, Sep.Oct. 2002.

KRUG, Etienne $G$ et al. The world report on violence and health. The Lancet, vol. 360, issue 9339, p. 1083-1088, Oct. 2002.

KUKURA, Elizabeth. Obstetric violence. The Georgetown Law Journal, vol. 106, issue $721,2018$.

MECANISMO de Seguimiento de la Convención Belém do Pará (MESECVI). Segundo Informe de Seguimiento a la Implementación de las Recomendaciones del Comité de Expertas del MESECVI. Mexico, D.F.: Organización de los Estados Americanos, 27 novembro 2014. OEA/Ser.L/II Disponível em: http://www.oas.org/es/mesecvi/docs/CEEP1-Doc10-ES.pdf. Access on: Abr. 16, 2019. 
MURRAY DE LOPEZ, Jenna. Conflict and reproductive health in urban Chiapas: disappearing the partera empirica' Anthropology Matters Journal, vol. 16, n. 1, 2015.

. When the scars begin to heal: narratives of obstetric violence in Chiapas, Mexico. International Journal of Health Governance, vol. 23, issue 1, p. 60-69, 2018.

RAMOS, André de Carvalho. Curso de Direitos Humanos. Saraiva: 2014 (digital version), seção 2.5.1.

REPÚBLICA BOLIVARIANA DE VENEZUELA. Ley Orgánica sobre el Derecho de las Mujeres a una Vida Libre de Violência. Gazeta Oficial No. 38.668, Abr. 23, 2007. Available at: <https://www.acnur.org/fileadmin/Documentos/BDL/2008/6604.pdf>. Accessed on: Apr. 16, 2019.

ROHDE, Ana Maria Basso. 'A outra dor do parto: género, relações de poder e violência obstétrica na assistência hospitalar ao parto. Dissertação de Mestrado Faculdade de Ciências Sociais e Humanas, Universidade Nova de Lisboa, Lisboa, 2016.

SANDALL, Jane et al. Short-term and long-term effects of caesarean section on the health of women and children. The Lancet, vol. 392, issue 10155, p. 1349-1357, Oct. 2018.

SAY, Lale e CHOU, Doris. Maternal morbidity: time for reflection, recognition, and action. Editorial. International Journal of Gynecology \& Obstetrics, vol. 141, suppl. 1, p. 1-3, May 23, 2018.

VACAFLOR, Carlos Herrera. Obstetric violence: a new framework for identifying challenges to maternal healthcare in Argentina. Reproductive Health Matters, vol. 24, issue 47, p. 65-73, 2016.

WILLIAMS, CR et al. Obstetric violence: a Latin American legal response to mistreatment during childbirth. BJOG, n. 125, p. 1208-1211, Jun. 2018.

WORLD HEALTH ORGANIZATION. The prevention and elimination of disrespect and abuse during facility-based childbirth, WHO/RHR/14.23, 2015.

WORL HEALTH ORGANIZATION and LONDON SCHOOL OF HYGIENE AND TROPICAL MEDICINE. Preventing intimate partner and sexual violence against women: taking action and generating evidence. Geneva: World Health Organization, 2010. 
ZANARDO, Gabriela Lemos de Pinho e. Violência obstétrica no Brasil: uma revisão narrativa. Psicologia \& Sociedade, vol. 29: el55043, 2017. 